\title{
Sinirbilim Araştırmalarında Taze Beyin Kesitleri: Fizyolojik Yöntemler, Avantajları Ve Kullanım Alanları
}

Fresh Brain Slices in Neuroscience Research: Physiological Methods, Advantages And Application Fields

\author{
Hilal ÖZTÜRK ${ }^{1}$ (D) , İsmail ABidiN ${ }^{1}$ \\ ${ }^{1}$ Karadeniz Teknik Üniversitesi Tıp Fakültesi Biyofizik Anabilim Dalı, Trabzon, Türkiye
}

Öz.

Nöronların ve nöronal devrelerin temel özelliklerini anlamayı hedefleyen sinirbilim çalışmaları, sinir sistemini farklı ölçeklerde incelemek için kullanılan farklı yaklaşımları içerecek şekilde zamanla genişlemiştir. Kullanılan metodların geliştirilmesiyle beraber bu çalışmalar hız kazanmıştır. Canlıı̆ın bütünüyle devam ettiği in vivo çalışmalar ve in vitro hücre kültür çalışmaları sinirbilim çalışmalarında sıklıkla kullanılmaktadır. Ancak, in vivo çalışmaların kısıtlayıcılığı ve in vitro kültür hücrelerinin sistemik yapıdan uzak oluşu sinirsel fonksiyonların açıklanmasında yetersiz kalmaktadır. Taze beyin kesitleri olarak bilinen yaklaşım klasik in vivo ve in vitro yaklaşımların erişiminden uzakta kalan alanların deneysel çalışmaları için uygun preparatlar olarak kabul edilmektedir. Hücreler arası bağlantıların korunuyor olması ve canlılı̆ı̆ı adaptif ve plastik süreçlerin incelenmesine imkan verecek kadar uzun olması beyin kesitlerinin sinir bilim çalışmalarında önemli yer tutmasına yol açmıştır. Akut beyin kesit hazırlığı, nöronların ve nöronal dokunun çeşitli fizyolojik koşullara nasıl tepki verdiğinin ayrıntılarını incelemek için ideal bir modeldir.

Beyin kesitleri çalışmalarında kesitlerin hazırlanma süreci, tasarlanan deneysel çalışmaya göre farklılık göstermektedir. Yüksek kalitede beyin kesitlerinin eldesi için, beyin kesitlerinin elde ediliş protokolü ve canlılığın uzun süre devam edebilmesi için yapay beyin omurilik sıvısının hazırlanması önemli süreçlerdir. Elektrofizyolojik kayıtların elde edilmesi esnasında; kesiti sağlıklı tutmak için uygun ortamın hazırlanmas $(\mathrm{pH}$, sıcaklık, osmolarite), optik donanımın sağlanması, mikroelektrotları sabit bir şekilde konumlandırmak için mekanik araçların temini ve elektronik sinyalleri yükseltme ve kaydetme araçları büyük öneme sahiptir. Bu derlemede, elektrofizyoloji çalışmalarında sıklıkla kullanılan diğer yöntemlerin yanı sıra taze beyin kesitlerinin kullanımı, gerekli ekipmanlar, deneysel prosedürler ve tekniğin sunduğu avantajlar açıklanmaktadır

Anahtar Kelimeler: Elektrobiyofizik, Ex-vivo kayit, Alan potansiyelleri, Yama-kenetleme.

\section{Abstract}

Neuroscience studies aiming to understand the basic properties of neurons and neuronal circuits have expanded over time to include different approaches used to examine the nervous system at different scales. These studies have gained momentum with the development of the methods used. In vivo studies and in vitro cell culture studies are frequently used in neuroscience studies. However, the limitations of in vivo studies and the out of systemic structure of in vitro culture cells are insufficient to explain neural functions. The approach known as fresh brain slices are considered to be suitable preparations for experimental studies of areas out of conventional in vivo and in vitro approaches. Preserved intercellular connections and long enough vitality to allow the study of adaptive and plastic processes have led to brain slices taking an important place in neuroscience studies. Acute brain slice preparation is an ideal model for studying the details of how neurons and neuronal tissue respond to a variety of physiological conditions.

The preparation process of the brain slices differs according to the designed experimental study. In order to obtain high quality brain slices, the protocol of obtaining brain slices and the preparation of artificial cerebrospinal fluid for long-term survival are important processes. During the acquisition of electrophysiological records; to keep the cross section healthy, the preparation of the appropriate environment $\mathrm{pH}$, temperature, osmolarity), the provision of optical equipment, the provision of mechanical tools to stabilize the position of the microelectrodes, and the equipments of amplifying and recording electronic signals are of great importance. In this review, the use of fresh brain slices, necessary equipment, experimental procedures and the advantages of the technique, as well as other methods frequently used in electrophysiology studies, are explained.

Keywords: Electrobiophysics, Ex-vivo recording, Field potentional, Patch-clamp
Sorumlu Yazar / Corresponding Author

İsmail ABídin

Karadeniz Teknik Üniversitesi,

Tıp Fakültesi, Biyofizik Anabilim Dalı, Temel Tıp Bilimleri Binası, 61080 Ortahisar,Trabzon, Türkiye

\section{E-mail: iabidin@ktu.edu.tr}

Geliş tarihi / Received: 13.08 .2021

Kabul tarihi / Accepted: 17.10.2021

DOI: $10.35440 /$ hutfd.982614 


\section{Taze Beyin Kesitleri: Ex-vivo preperatlar}

Sinirbilim çalışmalarında, in vivo olarak da bilinen canlılığın bütünüyle devam ettiği şartlarda yapılan çalışmalar önemli yer tutmaktadır. Ancak in vivo koşullar büyük ölçüde kısıtlayıcıdır. Uygulanan protokolün ikincil etkileri her zaman için düşünülmesi gereken bir faktördür. Özellikle merkezi sinir sistemi için düşünüldüğünde, kan-beyin bariyeri sistemik uygulanan kimyasalların/ajanların beyine geçişine izin vermeyebilir. In vivo çalışmaların alternatifi ise kültür hücreleri ile yapılan in vitro çalışmalardır. Kültür çalışmalarında, hücreler bir doku ve sistemden uzakta ve çoğunlukla tek olarak yaşarlar. Bu yöntemler sinirbilim çalışmalarında önemli yer tutsalar da sinirsel fonksiyonların açıklanmasında yetersiz kalmaktadırlar. Taze beyin kesitleri olarak bilinen yaklaşım klasik in vivo ve in vitro yaklaşımların erişiminden uzakta kalan alanların deneysel çalışmaları için uygun preperatlar olarak karşımıza çıkmaktadır. Her ne kadar beyinin bir bütün olarak vereceği sistem cevaplarının tamamı kesitlerde görülemez ise de hücreler arası bağlantıların korunuyor olması ve canlılığın adaptif ve plastik süreçlerin incelenmesine imkan verecek kadar uzun olması beyin kesitlerinin sinir bilim çalışmalarında önemli yer tutmasına yol açmıştır.

Taze beyin kesitleri ile yapılan ex-vivo çalışmalar, nöronal dokunun organizmadan bütünüyle çıkarılmasını ve deneysel süreç boyunca yapay ekstrasellüler sıvıda (artificial extracellular solution) canlı ve dinamik tutulmasını gerektirmektedir $(1,2)$. Kullanılan yapay ekstrasellüler sıvı, hücredışı ortamda bulunan çeşitli iyonları ve besinleri içerir ve enerji kaynaklarını sağlar. Kesit canlılığı için gerekli olan oksijenlenme de bu sıvının oksijenlenmesi ile karşılanır (3).

Beyin kesitleri çoğunlukla elektrofizyolojik kayıtların elde edildiği çalışmalarda kullanılırlar. Uzun süredir kullanılan bu teknik (2), beynin farklı bölgelerinin ve beyindeki elektriksel devrelerin fizyolojik, biyofiziksel ve farmakolojik olarak incelenmesini sağlar. Merkezi sinir sistemi ve sinaptik fenomenlerin araştırılmasında populer bir yere sahiptir. Taze beyin kesit analizleri, izole edilmiş spesifik reseptör fonksiyonlarını ve farmakolojisini araştıran in vitro hücre kültür deneyleri ile in vivo davranışsal farmakoloji deneyleri arasında önemli bir çarpraz fonksiyonel köprüyü temsil etmektedir. Iyon kanalları, sinaptik bağlantıların araştırılması gibi pek çok konuda çı̆̆ır açmış bir yöntemdir. Taze beyin kesitlerinin kullanılma sebebi sunduğu avantajlardan kaynaklanmaktadır. Tekniğin mekanik stabilitesi, uzun süreli kayıtlara izin vermektedir. $\mathrm{pO}_{2}, \mathrm{pCO}_{2}, \mathrm{pH}$ ve sıcaklık kolayca kontrol edilebilmekte ve istenilen şekilde ayarlanabilmektedir. Kesitlerle çalışırken kan-beyin bariyerinin bulunmaması çalışımak istenilen herhangi bir molekülün ekstrasellüler alana ulaşımını mümkün kılmaktadır. Ayrıca hücre kültürleri ve doku homojenatlarından farklı olarak yapısal bütünlük korunur. Kesit yapısının doğrudan görselleştirilmesiyle birlikte hem kayıt hem de uyarıcı elektrotların istenilen bölgelere yerleştirilmesine imkan vermektedir. Bu derlemede, elektrofizyoloji çalışmalarında sıklıkla kullanılan diğer yöntemle- rin yanı sıra taze beyin kesitlerinin kullanımı, gerekli ekipmanlar, deneysel prosedürler ve tekniğin sunduğu avantajlar açıklanmaktadır.

\section{Taze Beyin Kesitlerinin Hazırlanması} Yapay Beyin Omurilik Sıvısının Hazırlanması

Yapay beyin omurilik sıvısının (yBOS-artificial cerebral spinal fluid (aCSF)) bileşenleri, in vitro beyin kesiti hazırlığında hücre dışı ortamın kontrolü için temel unsurdur. Temel olarak yBOS, fizyolojik ekstrasellüler sıvının benzeri bir sıvıdır. yBOS farklı çalışmalar için farklı formüllerde hazırlanabilir ancak yüksek sodyum $(\mathrm{Na})$ ve klor $(\mathrm{Cl})$ iyon konsantrasyonları, daha az oranda potasyum (K) iyonu, nöronal fonksiyonlar için gerekli az miktarda kalsiyum (Ca) ve magnezyum $(\mathrm{Mg})$ iyonları, $\mathrm{pH}$ dengelemek için tampon ve besin olarak da glikoz içermektedir. Hazırlanan yBOS'nın içeriği, nöronal aktivitenin temel (baseline) seviyelerini (membran dinlenim potansiyeli, aksiyon potansiyeli hızı, transport mekanizma, hücre içi iyon bileşimi), metabolizmayı (enerji ile ilgili parametreleri, oksijen ve glikoz tüketimini) ve protein sentezini etkileyecektir (4). Beyin kesitlerinin yerleşik kullanımına karşın, farklı kesit çalışmalarında yBOS bileşenlerindeki önemli farklılıklar hakkındaki sorular varlığını sürdürmektedir. Kullanılan yBOS'ların iyonik bileşenleri karşılaştırıldığında en önemli farklılıkların $\mathrm{K}^{+}$ve $\mathrm{Ca}^{+2}$ konsantrasyonlarında olduğu görülmektedir. Bu iyonlar nöronlar üzerinde ciddi etkiler oluşturur ve bu nedenle konsantrasyonlarındaki farklılıklar önemlidir. Yapılan çalışmalarda $\mathrm{K}^{+}$seviyesindeki değişimlerin nöronların uyarılma popülasyonunda değişime, ATPazların aktivitesi ve protein sentezi gibi metabolik etkilere sebep olduğu rapor edilmiştir (5-14). In vitro çaIışmalarda kullanılan $\mathrm{Ca}^{+2}$ ve $\mathrm{Mg}^{+2}$ konsantrasyonlarındaki değişimin, kesitlerin fizyolojik özelliklerini etkilediğini, aksiyon potansiyeli eşiğini değiştirdiğini gösteren çalışmalar mevcuttur $(15,16)$. Ayrıca sinaptik iletim, $\mathrm{Ca}^{+2}$ iyon konsantrasyonundaki küçük değişikliklere oldukça duyarlıdır (1719). Çoğu fizyolojik tamponda serbest $\mathrm{Ca}^{+2}$ un bikarbonat ve fosfat anyonları ile kompleks oluşturması nedeniyle toplam $\mathrm{Ca}^{+2}$ konsantrasyonunun hesaplananın altında olabileceğine de dikkat etmek gerekmektedir (20). İyonik manipülasyonlar, kesitlerin aktivitelerini etkilemek için kullanılabilir. Bu nedenle hangi yBOS sıvısının kullanılması, yapılması planlanan deneyde hangi biyolojik sorunun araştırılmakta olduğuna göre belirlenmelidir.

Beyinde glikoz, yüksek plazma konsantrasyonu ve kan-beyin bariyerini aşan bol miktarda glikoz taşıyıcıları nedeniyle önemli bir enerji substratıdır (21). Tipik bir yBOS formülasyonunda kullanılan glikoz konsantrasyonu 10-11 mM olsa da 25 mM'a kadar arttırılabilir (22). Ayrıca artan glikoz konsantrasyonunun in vitro çalışmalarda nöroprotektif bir rol oynadığı düşünülmektedir $(23,24)$. (Tablo 1$)$.

Gerçek beyin omurilik sıvısının $\mathrm{pH}$ aralığı ve osmolaritesi sırasıyla 7,27-7,42 ve 289-315 mOs'dur. yBOS hazırlanırken çoğu araştırmacı tampon olarak bikarbonat kullanmasına ragmen, Hepes ve tris kullanımı da rapor edilmiştir $(15,28)$. $\mathrm{pH}^{\prime}$ taki değişikliklerin boşluk bağlantı (gap junction) geçir- 
genliğini (29) ve membran potansiyelini (30) etkilediği bilinmektedir. Bu nedenle yBOS'nın pH stabilitesinin sağlanması önemlidir. Ayrıca beyin kesitleri oksijen seviyelerine oldukça duyarlıdır. Beyin kesitleri hazırlanırken kısa bir hipoksik dönem geçirir. Çoğu kesitlerin sonunda iyileştiği hipoksik ataklarla ilgili görüşler bildirilmiştir (31). Beyin kesitlerinin oksijenlenmesi, yBOS içerisinde gerçekleşir ve kesit yüzeyinde oluşan $\mathrm{pO}_{2}$ yaklaşık $675 \mathrm{mmHg}$ olmalıdır.

Tablo 1. Beyin kesitleri için kullanılan çeşitli yBOS bileşimleri (mM) $(25,26,27)$

\begin{tabular}{|c|c|c|c|c|c|c|c|c|c|}
\hline Tür & Kesit & $\mathrm{Na}^{+}$ & $\mathrm{K}^{+}$ & $\mathrm{Mg}^{+2}$ & $\mathrm{Ca}^{+2}$ & $\mathrm{Cl}^{-}$ & $\mathrm{HCO}_{3}$ & Glikoz & $\mathrm{H}_{2} \mathrm{PO}_{4}$ \\
\hline Sıçan & Hipokampüs & $150-152$ & $3,5-6,2$ & $1,3-2,4$ & $1,5-2,5$ & $132-136$ & $24-26$ & $4,0-10,0$ & $1,2-1,4$ \\
\hline Kobay & Hipokampüs & $143-150$ & $5,4-6,2$ & $1,3-2$ & $2-2,5$ & $127-133$ & $26-26,2$ & $10,0-11,0$ & $0,92-1,25$ \\
\hline Fare & Hipokampüs & 151,25 & 2,5 & 1,5 & 2 & 134,5 & 25 & 25 & 1,25 \\
\hline
\end{tabular}

Beyin kesitlerinin başarı ile korunduğu sıcaklık, oda sıcaklığı ile deneyde kullanılacak hayvanın vücut sıcaklığı arasında değişmektedir. Örneğin çalışmada sıçan ve kobay gibi bir kemirgen kullanılıyorsa bu sıcaklık $38-39^{\circ} \mathrm{C}^{\prime}$ ye kadar çıkabilmektedir. Ancak yapılan araştırmalarda beyin dokusunun vücut sıcaklığından daha düşük sıcaklıklarda daha sağlıklı ve uzun süre hayatta kaldığı bulunmuştur. Bu sıcaklık değeri 30-35 ${ }^{\circ} \mathrm{C}$ aralığında değişmektedir.

Hazırlanan yBOS solüsyonu kesit alma, inkübasyon ve kayıt alma aşamaları için değişkenlik göstermektedir. Diseksiyon sırasında metabolizmayı yavaşlatmak ve $\mathrm{Ca}^{+2}$ bağımlı eksitotoksisiteyi en aza indirmek için soğuk $\left(1-4^{\circ} \mathrm{C}\right) \mathrm{Ca}^{+2}$ içermeyen bir yBOS veya kesme solüsyonu (cut solution) olarak isimlendirilen bir solüsyon kullanılmaktadır. Bir kesme solüsyonunun kimyasal bileşimi için kullanılan 3 farklı solüsyon vardır. Bunlardan ilki, NaCl'ün yarı miktarı yerine sükroz eklenmesi veya $\mathrm{NaCl}$ konsantrasyonuna eşmolar konsantrasyonda sükroz ile değiştirilmesidir. Diğeri, $\mathrm{Ca}^{+2}$ konsantrasyonunun azaltılması veya tamamen kaldırılması ve $\mathrm{MgSO}_{4}$ (veya $\mathrm{MgCl}_{2}$ ) arttırılması ile elde edilen solüsyondur. Son olarak, nöral hücreleri hipoksi ve iskemi hasarından korumak için NMDA reseptör antagonistlerinin veya diğer reaktiflerin eklendiği bir kesme solüsyonu da mevcuttur. En sık kullanılan kesme solüsyonunun kimyasal bileşimi Tablo 2'de verilmiştir.

Tablo 2. Sukroz içerikli kesme solüsyonu kimyasal formülasyonu (mM). (32)

\begin{tabular}{lllllll}
\hline Sukroz & $\mathrm{NaHCO}_{3}$ & $\mathrm{KCl}$ & $\mathrm{NaH}_{2} \mathrm{PO}_{4}$ & $\mathrm{CaCl}_{2}$ & $\mathrm{MgSO}_{4}$ & Glikoz \\
230 & 26 & 3 & 1,25 & 0,5 & 10 & 10 \\
\hline
\end{tabular}

Düşük $\mathrm{Ca}^{+2}$ içeren yBOS solüsyonunun içerisine $\mathrm{CaCl}_{2}$ eklenerek kesitlerin dinlendirileceği "dinlenme solüsyonu" hazırlanır. Dinlenme solüsyonu kayıt sırasında kullanılabileceği gibi deney planlamasına gore bu solüsyona ekleme/çıkarma yapılarak "kayıt solüsyonu" hazırlanmış olur.

\section{Beyin Kesitlerinin Hazırlanması}

Genel olarak kemirgenler (sıçan, fare, kobay) beyin kesit çaIışmalarında tercih edilen deney hayvanlarıdır. Beyin diseksiyonu, sağlıklı kesitler üretmede en önemli faktör olabilir. Araştırmalar genç hayvanların, yaşlı hayvanlardan daha iyi sonuçlar verdiğini göstermektedir. Bunun nedeni ince kafa- taslarının daha kolay çıkarılması ve daha az travmatik bir diseksiyona izin vermesinden kaynaklı olabilir. (33). Kesim öncesi hayvana anestezi uygulanabilir yada direkt hayvanın başı kesilip diseksiyon yapılabilir. Dokunun çıkarılması ve dilimlenmesinde gösterilen hız ve özenin, diseksiyon hızından daha önemli olduğu düşünülmektedir. Ayrıca dokunun nasıl dilimlendiğinin elektrofizyolojik ve histolojik kriterlere göre değerlendirilmesinde kesitlerin kalitesinde büyük farklılığa yol açtığı gösterilmiştir (34).

Beyin dilimlemede elle kesme veya chopper kullanımı uygulandıysa da (2) günümüzde daha sıklıkla tercih edilen diğer metod ise, vibratom (veya mikrotom) kullanmaktır. Bu yöntemde beynin tamamı yada ilgili bölümü cihaza ait teflon bir platforma sabitlenir ve kesme solüsyonu içerisinde, ayarlanabilir hızda istenilen kalınlıkta beyin kesitleri alınır. Bu metodla elde edilen kesitlerin kalitesi oldukça yüksektir ancak beyin dokusu zarar görmeden cihaz platformuna sabitlemek tecrübe gerektirmektedir. Şekil 1'de gösterildiği gibi farklı kesimde kesitler almak mümkündür.

Tüm bu dilimleme işlemleri baş kesildikten sonra hızlı bir şekilde yapılmalıdır.

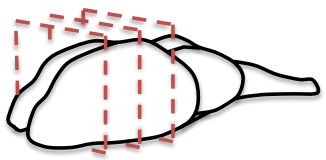

Koronal kesit

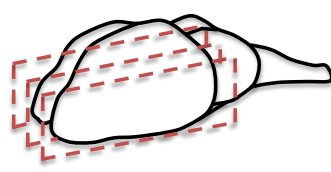

Sagital kesit

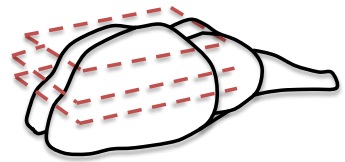

Horizontal kesit

Şekil 1. Fare beyni şematik çizimi üzerinde farklı kesit alma gösterimi.

Beyin kafatasından çıkarılmalı, ve $\% 95$ oksijen $\% 5$ karbondioksit olan gaz karışımı ile dengelenmiş, soğuk (1-5 $\left.{ }^{\circ} \mathrm{C}\right)$ yBOS içerisine alınmalı, kısa süreli dinlenimin ardından dilimleme için uygun hale getirilmelidir. Kullanılan yöntemlerle 100$500 \mu \mathrm{m}$ kalınlıkta kesitler almak mümkündür. Kesit kalınlığı belirlerken, kesitin görünürlüğü, canlılığı ve nöronal devrelerin korunmasına dikkat edilmelidir. Elde edilen kesitler deneysel olarak kullanılmadan önce genellikle 30 dakika-2 saat arası bir süre dinlendirilmelidir. Bu dinlenme süresinde 
kesitler, travma durumundan çıkarlar, kesilme işlemi sırasında kesitlerin yüzeyine yakın bölgelerde yaralanan hücreler ölür, kesitlerin orta derinliklerinde yaşayan hücreler de belirli bir denge durumuna gelirler. Kesitler, dinlenme çemberlerinde yBOS içinde bulunurlar ve devamlı olarak oksijenlenirler (Şekil 2).

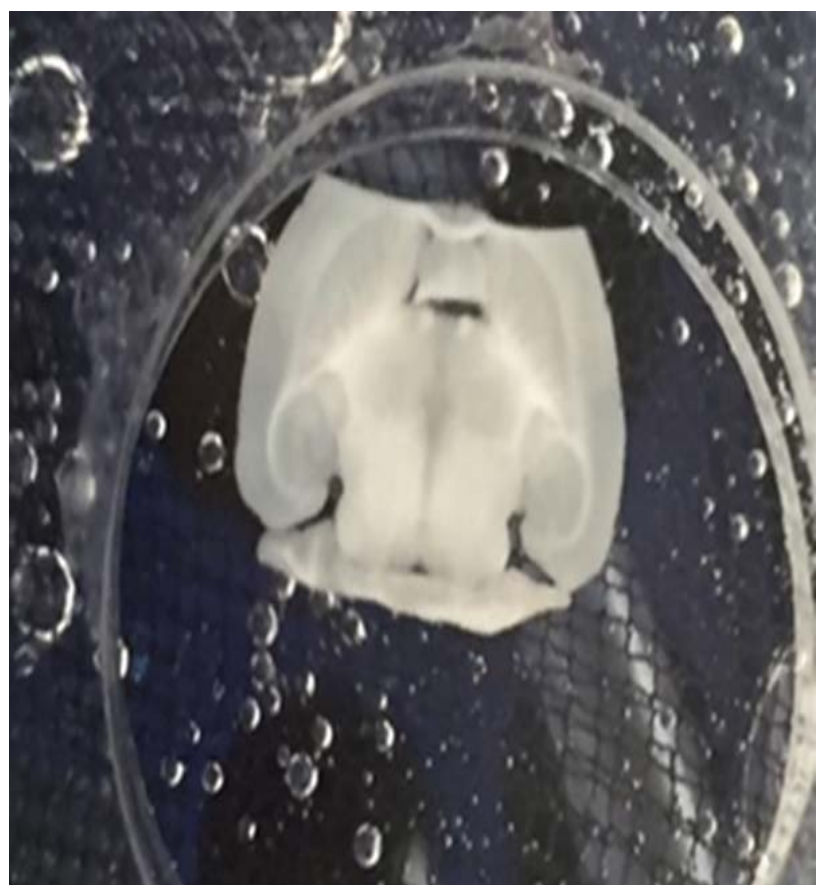

Şekil 2. Dinlenme çemberi içerisinde horizontal beyin kesiti (hipokampüs).

\section{Taze Beyin Kesitlerinin Deneysel Kullanımı 3.1. Elektrofizyolojik Kayıtlar} Kayıt Çemberi (Odası)

Kesitler elde edildikten sonra, oksijenli yBOS içeren bir kaba alınır ve gerekli inkübasyon ve kayıt işlemleri için pipetle kayıt çemberine aktarılır. Kesitlerin deney boyunca tutulacağı böylesi bir ortam uygun oksijenlenme, osmolarite ve sıcaklığı karşılamalıdır. Bazı araştırmacılar statik havuz çemberi (static-pool chamber) tasarımı kullanmasına rağmen (33), en yaygın kullanılan tasarım White ve arkadaşları tarafından geliştirilen süperfüzyon çember tasarımıdır (35). Bu çemberler kesit boyunca yBOS'nın süperfüzyonuna izin verir. Süperfüzyon odası tasarımlarında, kesitler ya gaz-sıvı arayüzeyinde (interface chamber) bir ağ üzerinde durur veya tamamen sıvı içerisine batırılır (submersion chamber). Farklı çember tasarımlarının her biri farklı avantajlar sunar. Oslo kayıt çemberi (Oslo chamber) olarak adlandırılan bir arayüz çemberinde $(36,37)$ kesitler, yBOS'nın yüzey gerilimini azaltan ve yBOS'nı kesitlere eşit olarak dağıtan bir mercek kağıdı çemberinde durur. yBOS, kesitlerin altından içeri girer ve burada eşmerkezli bir hendeğe boşaltmak için kesitlerin üzerlerinden ve etrafından akar. Sıvı yüksekliği aspi- rasyonla kontrol edilir, Her bir kesitin üst yüzeyi yBOS'nı yalnızca kılcal akışla alır. Bu durum difüzyonu yavaşlatır ve kesitlerin üst yüzeylerinin kurumasına yol açabilir. Haas ve arkadaşları tarafından Oslo tasarımında değişiklikler yapılıp yeni bir arayüz çemberi tanımlanmıştır (38). Ancak kesit yüzeylerinin kurutulması tüm arayüz çemberlerinin ortak sorunudur.

Kesitleri tamamen sıvı içerisine daldırma tasarımı kesit yüzeylerinin kuruma sorununu ortadan kaldırmıştır ve farmakolojik çalışmalar için kullanışı hale getirmiştir (Şekil 3). Bu çember sistemi kullanılan molekül, iyon ve ilaçların dokuya difüzyonunu optimize eder. Ancak bu sistemde suya daldırma mercekli mikroskop kullanılmazsa elektrotların görselleştirilmesi zor olabilir.

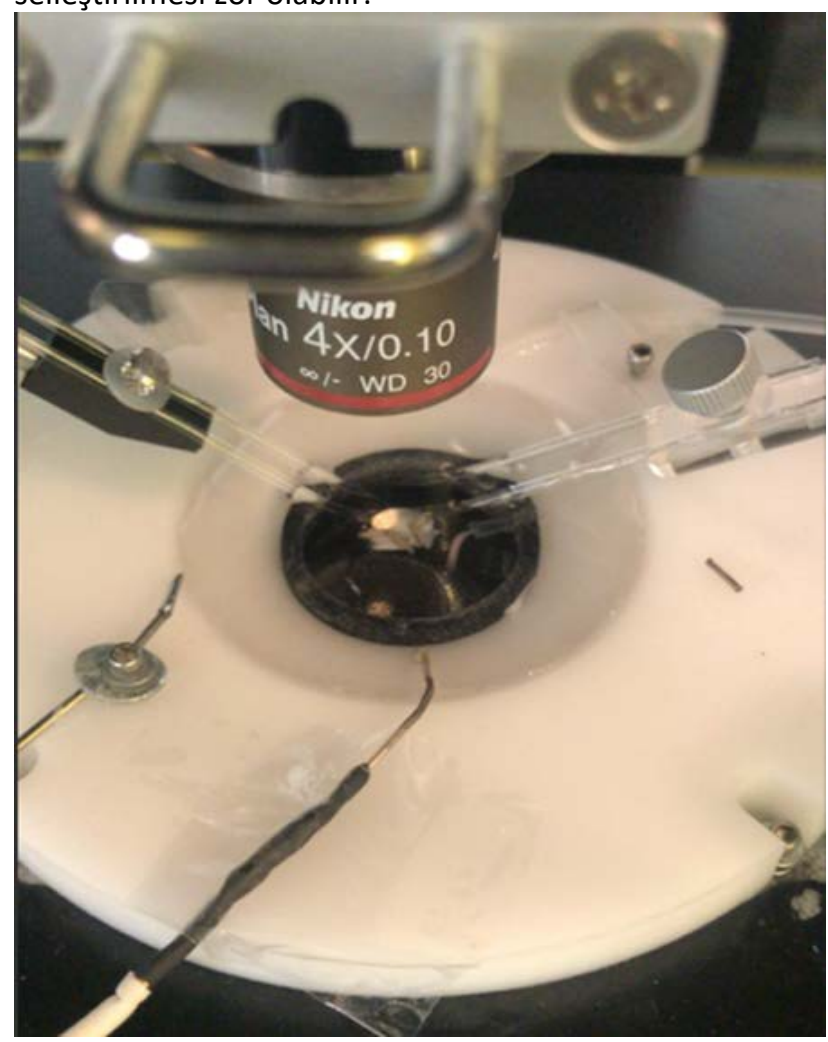

Şekil 3. Kesitlerin tamamen yBOS içerisine daldırıldığı çember sistemi.

Süperfüzyon kayıt çemberi, harici bir saklama kabına veya taze yBOS'nı tutan bir şişeye bağlanır (3). yBOS harici kapta oksijenlenerek, kayıt çemberine sabit hızda aktarılır (dakikada birkaç mililitre). Kayıt çemberinde bulunan bir başka tüp çemberde bulunan yBOS'nı atık kabına götürür (1,3, 35). Bu şekilde kesit bulunduğu çemberde devamlı taze yBOS ile perfüze edilmiş olur (Şekil 4). Beyin kesit çalışmalarında kullanılmış farklı süperfüzyon tasarımları mevcuttur $(5,39)$. Her iki tasarım da deneysel amaçlara ve hedeflere bağlı olarak çalışılabilirdir. 


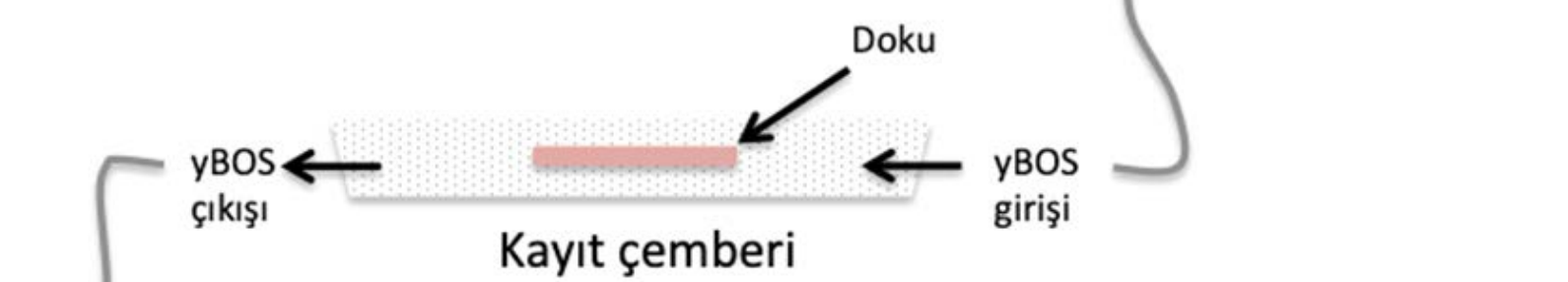

\section{Atık kabı}

Şekil 4. Süperfüzyon kayıt çemberi.

\section{Deneysel Düzenek}

Beyin kesitlerinden elektrofizyolojik kayıtlar elde ederken genel amaç, dokunun in vivo deneyimlediği ortamı mümkün olduğunca yakından taklit eden bir ortam hazırlamak ve bu ortamda dokunun hücre dışı alanında bir elektrot ile sinyal almaktır. Bu nedenle kesitin konulacağı, doku sıcaklığını koruyan (ısıtıcı kaynak), oksijenlendiren ve perfüze eden bir çember (odacık) gereklidir. Son zamanlarda aynı

A anda birden çok beyin kesitinden kayıt yapabilme avantajını sağlayan, böylece hayvan kullanımını azaltan ve veri kalitesini yükselten birkaç çok kesitli elektrofizyoloji sistemi tanımlanmıştır (40-42).

Bir elektrofizyolojik kurulumun dört ana bileşeni vardır (Şekil 5).

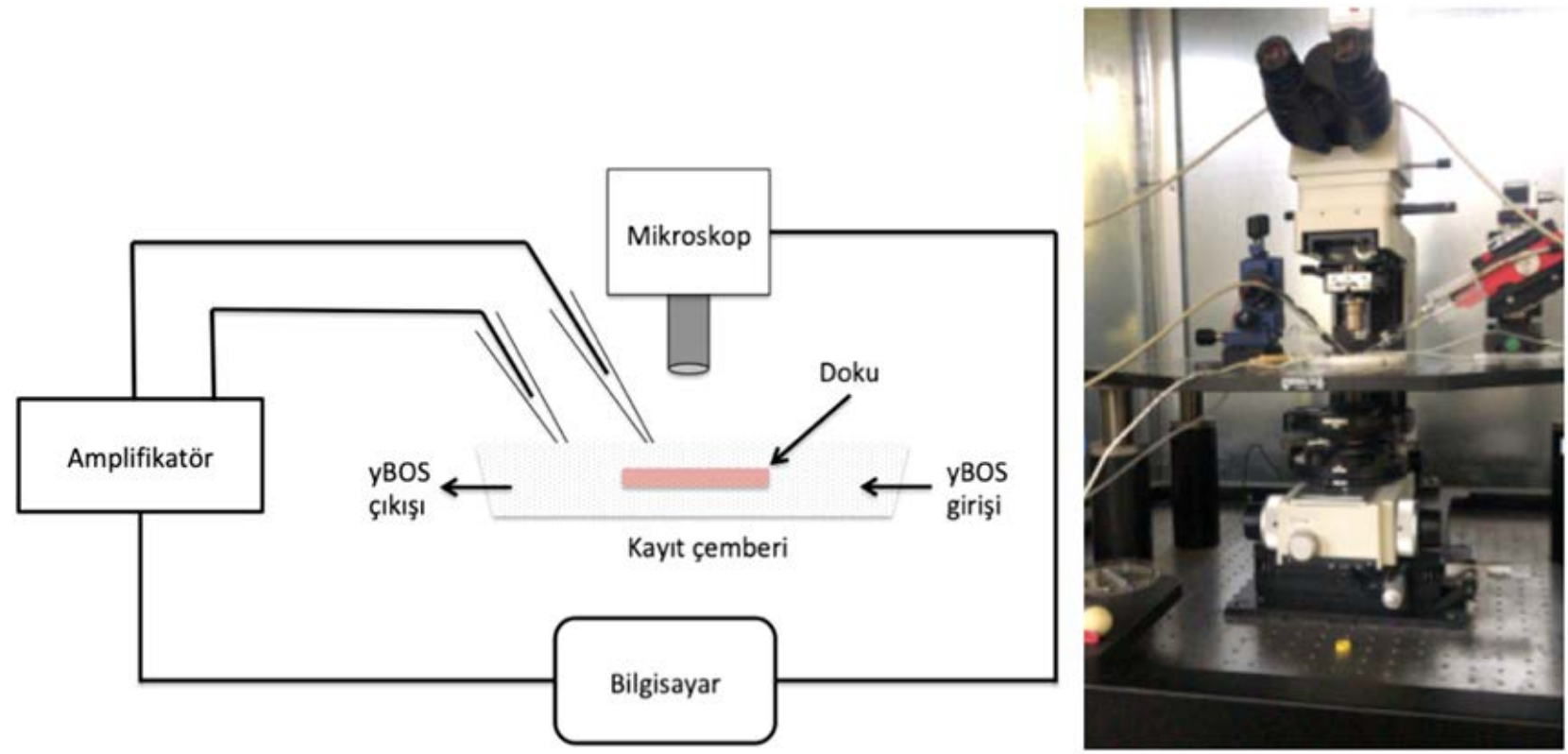

Şekil 5. Deneysel düzeneğin A) şematik ve B) gerçek gösterimi. 
Bunlar; kesiti sağlıklı tutmak için uygun ortamın hazırlanması, optik donanımın sağlanması, mikroelektrotları sabit bir şekilde konumlandırmak için mekanik araçların temini ve elektronik sinyalleri yükseltme ve kaydetme araçlarıdır. Ayrıca çalışma ortamının titreşim ve elektrik izolasyonunun yapılması gerekmektedir.

Kesiti daha yakından görmek ve mikroelektrotları istenilen doku bölgesine yerleştirebilmek için düşük güçlü bir mikroskop yeterli olmaktadır. Voltaj kenetleme sisteminde zorunlu olan sabit izole masa ortamı bu çalışmalar için zaruri değildir. Ayrıca mikromanipülatörler kayıt esnasında kayma titreme yapmamak koşuluyla kaba mekanik tipte olabilirler. Mikro elektrot amplifikatörü ve bir bilgisayar elektriksel sinyallerin yakalanması için bulunması gereken temel araçlardır. Kullanılan amplifikatörün kazancı en az 1000 olan düşük gürültülü bir voltaj yükseltici olmasına dikkat edilmelidir (43).

\subsubsection{Kesitlerde Patch-Clamp Uygulamaları}

Patch clamp (yama kenetleme), bir membran parçasına uygulanan voltojın membran parçasında oluşturduğu akımın ölçülmesiyle iletkenliği hakkında bilgi veren bir elektrofizyolojik kayıt yöntemidir. Kenetleme yöntemi sadece voltaj için değil, akımın belirlenen bir değerde kenetlenmesi ile bir membran parçası boyunca oluşan voltajı ölçmek için de uygulanabilir. Bu teknik 1986'da Neher ve Sakmann tarafından tanıtılmıştır (44). Zamanla farklı konfigürasyonlar kullanılarak geliştirilen tekniğin günümüzde kullanılan 5 farklı konfigürasyonu bulunmaktadır. Bunlardan ilki olan "cell attached patch" (hücre bağlı yama) kayıt alma elektrodunun basınç uygulanarak membranın küçük bir parçasına sıkıca kenetlenmesini sağlamaktadır. Yaklaşık 1-2 $\mu \mathrm{m}$ açıklığa sahip bir mikroelektrot kullanıldığında, elektrot ve hücre membranı arasında kimyasal ve elektriksel olarak kararlı bir bağlantı oluşur. Gigaohm $(G \Omega)$ seviyesinde olan yüksek elektrik direnci nedeniyle "gigaseal" olarak adlandırılır. Bu durum düşük arka plan gürültüsü ile pA aralığındaki akımların kaydedilmesini sağlamaktadır. Bu direncin oluşturulması, hedeflenen kayıtta gürültünün azaltılması, membran voltajının zaman ve genlik kontrolünün sağlanması için gereklidir. "Cell attached patch" genel olarak diğer konfigürasyonların temelini oluşturmaktadır. Elektrod içerisinde bulunan sıvı ve sitoplazma arasındaki membran parçası, sıkıca mühürlenmiş pozisyondayken pipete uygulanan ters basınç (emme) ile membran bütünlüğü bozulur (45). Buna tam hücre konfigürasyonu (whole cell) denilmektedir. Bu pozisyonda pipet yavaşça çekilir ve kesilmiş yama elde edilir. Bu konfigürasyona dış-dış yama (outside out patch-OOP) denilmektedir. Pipet "Cell attached patch" pozisyonundayken, aniden çekilerek çıkarıldığında ise elde edilen membran parçası içten dışa yama (inside out patch-IOP) olarak adlandırılır. Çünkü plazma zarının içi artık yapay ekstrasellüler sıvı ortamına maruz kalmaktadır. Çoğu zaman hücre, hasarlı membranı yeniden mühürler ve bu işlemler aynı hücrede tekrar gerçekleştirilebilir. Beşinci konfigürasyon, "cell attached patch" pozisyonunda hücre membranının kırılmadığı, ancak hücre içine erişim için pipet solüsyonu aracılığıyla yapay iyon kanalları eklenerek geçirgen hale getirildiği geçirgenleştirilmiş yama tam hücre (permeabilized-patch WC) konfigürasyonudur (46). Şekil 6'da patch-clamp konfigürasyon diyagramı gösterilmektedir.

Hücresel elektrik sinyalleri üretmenin temeli, hücrenin özel membran taşıyıcıları ve kanalları aracılığıyla kimyasal/elektriksel gradyanlar oluşturarak bir kapasitör boyunca elektriksel potansiyeller üretme kabiliyetinde yatar. Hücre zarları boyunca elektriksel potansiyelin büyüklüğü birkaç milivolt$\tan$ (sinaptik potansiyeller), 100 mV'un üzerine (aksiyon potansiyelleri) kadar değişir. Elektrik akımları, iyonların mambran boyunca akmasına izin veren iyon kanallarının açılıp kapanmasıyla üretilir ve birkaç pikoamperden (tek bir kanalın açılması), nanoamperlere kadar (binlerce kanalın eş zamanlı açılması) değişir. Patch clamp tekniği, membranı elektriksel olarak izole eder ve arka plan gürültüsünü en aza indirir. Bu nedenle kanal aktivitesini doğru bir şekilde karakterize etmek için güçlü bir yöntemdir. Patch clamp kayıtlarında iki ana mod vardır: voltaj kenetleme ve akım kenetleme. Voltaj kenetleme modunda, membran voltajı amplifikatör tarafından kayıt pipeti aracılığıyla kontrol edilir ve pipet boyunca karşılık gelen akım ölçülür. Akım kenetleme modunda, amplifikatör pipetten geçen akım miktarını kontrol eder ve buna karşılık gelen voltaj değişikliği ölçülür. Voltaj kenetleme modunda akım, iletkenlik ile doğru orantılıdır. Bu teknik ile membran dinlenim potansiyelini ve aksiyon potansiyelini ölçmek mümkündür. Şekil 7'de patchclamp tekniğiyle alınmış sinyal kayıt örneği gösterilmiştir. Patch clamp tekniği, pasif ve aktif membranı nicel olarak tanımlama yeteneği açısından önemli olduğu gibi aynı zamanda elektrofizyolojik davranışının altında yatan mekanizmaların daha derinlemesine anlaşılmasına katkısı açısından da önemlidir. Membran iletkenliğindeki değişiklikler (kanaldan geçen iyonların oranı) dahil olmak üzere tek bir kanalın aktivitesindeki değişiklikleri gerçek zamanlı olarak gözlemleme yeteneği sağlayan bu yöntem, belirli iyon kanallarının voltaj, iyon ve ligandlara karşı hassasiyetlerinin belirlenmesine izin verir. Bu teknik, çeşitli iyon kanalı türlerinin keşfedilmesini ve bunların sınıflandırılmasını sağlamıştır. İyon kanallarının elektriksel ve kinetik özellikleri açıklanmış ve bu kanalların fizyolojik modülasyonu ve ayrıca hastalık durumlarındaki değişimleri hakkında fikir vermiştir. İyon kanallarındaki kusurlarla birçok hastalık ilişkilendirilmiştir (47). Ayrıca iyon kanalı modülatörlerinin mekanizmalarını anlamak için farklı konformasyonel durumlarda bir ilaç ile belirli bir iyon kanalı arasındaki etkileşimi aydınlatmak için kullanılmıştır. Örneğin; epilepsi, diyabet, hipertansiyon ve ağrı dahil birçok hastalığı tedavi etmek için kullanılan iyon kanalı modülatörlerinin farmakolojik özelliklerini incelemek için yapılmış çalışmalar bulunmaktadır (48). 
A

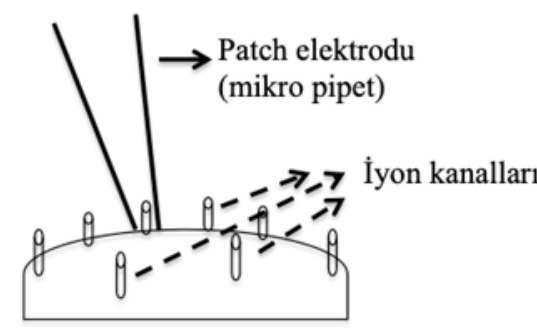

Cell attached patch
B

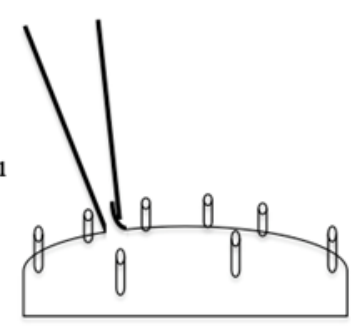

Whole cell patch
C

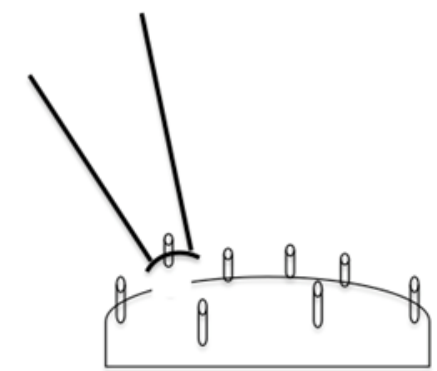

Inside out patch

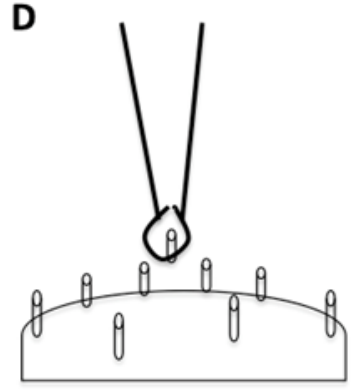

Outside out patch

E

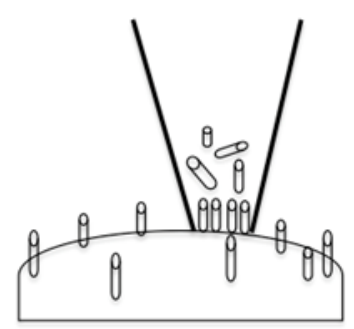

Permeabilized patch-WC

Şekil 6. 5 farklı patch clamp konfigürasyon diyagramı. Şekil, ekstrasellüler sıvıya daldııımış yandan görülen canlı bir hücreyi temsil etmektedir. A) Hücreye bağlı yama (cell attached patch) B) Tam hücre yaması (whole cell patch) C) İ̧̧ dış yama (inside out patch) D) Dış dış yama (outside out patch) E) Geçirgenleştirilmiş yama (permeabilized patch).

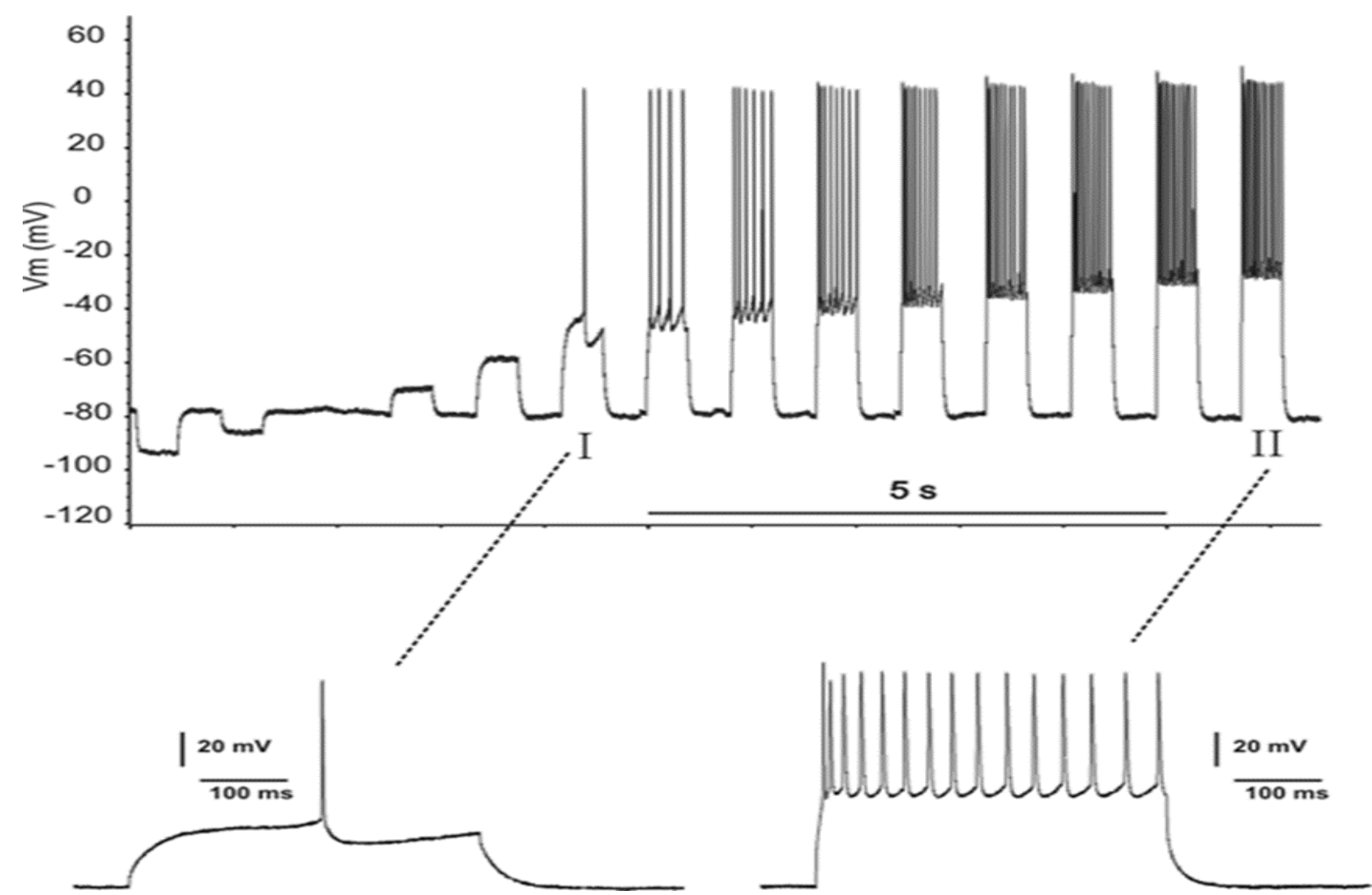

Şekil 7. Hiperpolarize ve depolarize edici akım enjeksiyonlarına yanıt olarak elde edilen temsili elektrofizyolojik kayıt örneği. 
Sistemde kullanılan kayıt cihazları, çok yüksek bir giriş empedansına $\left(10^{12}-10^{15} \mathrm{~m} \Omega\right)$ ve $\mathrm{mV}$ aralığında düşük gürültüye sahip, yüksek kazançlarda yeterli bant genişliğine sahip FET (Field effect transistor-Alan etkili transistor) işlemsel amplifikatörlerdir. Ayrıca genel bir ex-vivo kayıt düzeneğine ek olarak, uygulamanın hassasiyeti nedeniyle titreşimsiz masa kullanılması ve dış elektromanyetik alanları uzaklaştırmak için Faraday kafesi kullanımı zaruridir. Ayrıca patch clamp tekniğinde kullanılan kayıt elektrotlarının içerisine ekstrasellüler kayıt pipetlerinden farklı olarak özel bir solüsyon hazırlanır.

\subsubsection{Kesitlerden Ekstrasellüler Alan Potansiyel Kayıtları}

Beyin tarafından bilginin depolanması, birbirine bağlı büyük nöron ağlarında meydana gelmektedir. Iletişim kuran nöron kümesindeki aktivitenin, ağı oluşturan nöronlar arasında değişmiş sinaptik bağlantı güçleri olarak gösterilen hafızayı oluşturduğuna inanılmaktadır (49). Hipokampüsün limbik korteksi de dahil olmak üzere korteks bölgelerinden alınan beyin kesitleri, bu ağdaki bireysel sinapslarda meydana gelen değişikliklerin altında yatan hücresel süreçleri tanımlamada ve anlamada son derece yararlı olmuştur (50).

Beyin kesitleri, hafizanın altında yatan değişmiş sinaptik kuvvetlerin hücresel yönlerinin, uzun vadeli sinir uyarılarının gücündeki artışın (long term potentiation-LTP) ve sinaptik kazançta uzun vadeli bir azalma olan uzun vadeli depresyonun (long term depression-LTD) aydınlatılmasında kullanılan en önemli metoddur. Sinaptik iletimde LTP'nin, nöronal ağlarda anıların kodlanmasında önemli bir rol oynadığı kabul edilmektedir $(51,52)$. Bu fenomen ilk olarak bir in vivo preparatta keşfedilmiştir (53) ancak mekanizmanın çözülmesindeki en önemli gelişmeler in vitro beyin kesitlerinden elde edilmiştir (54-60). LTP ve LTD'nin tipik bir beyin kesiti çalışması, ilgili post sinaptik hücrelere öncülük eden uyaranları etkinleştirmek için stimülasyon elektrodu kullanmayı gerektirir. Monosinaptik uyarıcı post sinaptik potansiyeller (EPSP), hücreiçi veya tam hücre kayıt teknikleri kullanılarak nöronlardan veya alan kayıt teknikleri kullanılarak nöron popülasyonlarından kaydedilebilir. LTP veya LTD'yi oluşturmak için afferentlere tekrarlayan stimülasyon uygulanır. LTD, düşük frekanslı bir stimülasyonla $(2-7 \mathrm{~Hz} /$ 100 'lerce uyarım) indüklenirken, LTP yüksek frekanslı bir stimülasyonla (50-400 Hz/saniye) indüklenir. Yapılan beyin kesiti çalışmaları, ön beyin sinapslarının iki farklı LTP formu sergilediğinin gösterilmesini sağlamıştır (61). Beyin kesit metodu, bireysel sinapslarda meydana gelen sinaptik değişikliklerin doğasını ve mekanizmalarını anlamada yüksek ölçüde fayda sağlamıştır. Sinaptik kazanç değişikliklerine NMethyl-D-aspartat (NMDA), $\alpha$-amino-3-hidroksi-5-metil-4izoksazolpropiyonik asit (AMPA) ve metabotropik glutamat reseptörlerinin katkıları hakkında mevcut bilgilerin neredeyse tamamı beyin kesit çalışmalarından sağlanmıştır. Bir beyin kesitinde spesifik bir yolağı uyarmak ve nöronal ağın korunduğu beyin bölgelerinde belirli postsinaptik hücreleri diğer sinaptik girdilerin kontaminasyonu olmadan kaydedebilmek mümkündür. Çünkü bu metod, sinaptik bir yapıyı karıştırıcı ağ etkilerinden izole eder ve kontrollü çevresel koşullarda incelemeye olanak sağlar. Bu konulardaki mevcut bilgimiz çoğunlukla hipokampal kesitlerdeki çalışmalardan kaynaklanmaktadır.

Beyin kesitlerinin yaygın olarak kullanıldığı bir diğer araştırma alanı ise epileptik olmayan beyin dokusu kesitlerinde nöbet benzeri olaylar geliştirmektir. Hücre dışı $\mathrm{Ca}^{+2}$ ve $\mathrm{Mg}^{+2}$ içermeyen çözeltiler $(4,16,62)$, artmış hücre dışı $\mathrm{K}^{+}(63)$ epileptiform aktivite oluşumuna yol açan sinir ağı uyarılabilirliğinde önemli bir artışa neden olur. Ayrıca Pentilentetrazol (PTZ), NMDA, tetanik kontraksiyon toksinleri veya Gamaaminobütirik asit (GABA) reseptör antagonistleri (penisilin, pikrotoksin, bikukulin) gibi bileşiklerin kesit perfüzyonuna eklenmesi ile nöbet benzeri olaylar geliştirilmektedir (64). Bu deneysel modeller akut nöbet oluşum modellerini (iktogenez) temsil etmektedir. In vitro beyin kesitlerinde epileptiform aktiviteyi indükleyen $\mathrm{K}^{+}$kanal blokörü 4AP (4-aminopiridin) de kullanılmaktadır (65-70). Bu modelde, ilaçla uzun süreli perfüze olan kesitte nöbet benzeri iktal deşarjlar, tahmin edilemeyen zaman ve alanlarda kendiliğinden ortaya çıkmaktadır (68) (Şekil 8).

Kesitlerin, ayrıntılı hücresel ve sinaptik fenomenleri araştırmak için sahip oldukları teknik avantajlar, temporal lob epilepsisi (TLE) ve epileptogenez modellerinin incelenmesinde özellikle önemli olmuştur. Genel olarak epileptojenik bir olay veya uyaranı izleyen iki dönem araştırılmıştır: kendiliğinden tekrarlayan nöbetler gösterdiği kronik epilepsi fazı (epilepsi) ve ilk travma ile ilk spontan nöbet arasındaki süreç (epileptogenez) olan latent dönem. Kronik hayvan modellerinden hipokampal kesitleri incelemenin en önemli avantajı, bu hayvanların epileptik olmalarıdır. Hayvanda oluşturulan epileptik durumla ilişkili veya nedensel olarak iktogenez ile ilişkili olabilecek parametreleri analiz etmek bu modelde mümkündür. Ancak, epileptik hayvanlardan alınan kesitlerde fizyolojik koşullar altında interiktal benzeri veya iktal benzeri deşarjların meydana geldiği bildirilmemiştir (72). Bunun yanısıra, kronik modeller kesitlerin epileptik eğilimini ortaya çıkarmak için kullanılabilir. Kontrol ve epileptik kesitler arasında interiktal benzeri veya iktal benzeri aktivitenin modelini ve özelliklerini karşılaştırmak, epileptogenez sırasında veya epilepsinin kronik aşamasında meydana gelen fonksiyonel yapılanmalar (uyarıcı aksonların filizlenmesi) hakkında önemli bilgiler ortaya çıkabilir (7378). Bu kesitlerin başka bir kullanımı, epileptik durumla ilişkili hipokampal devre değişikliklerinin ayrıntılarını araştırmaktır. Birçok çalışmada elektrofizyoloji, fonksiyonel morfoloji veya moleküler biyolojiyi birleştiren multidisipliner bir yaklaşıma dayanmaktadır (79-88). Epilepsi modelinde verilerin yorumlanması karşılaşılan en önemli zorluktur. 
A

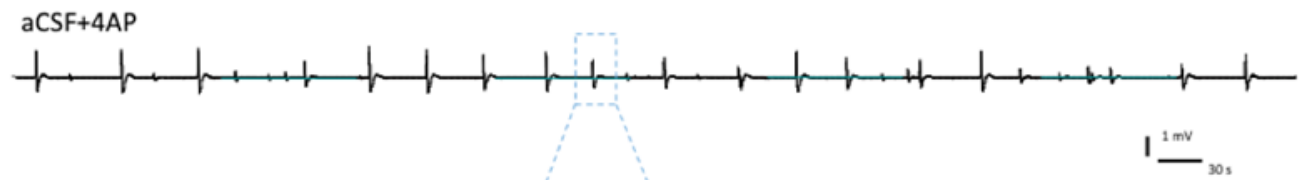

B

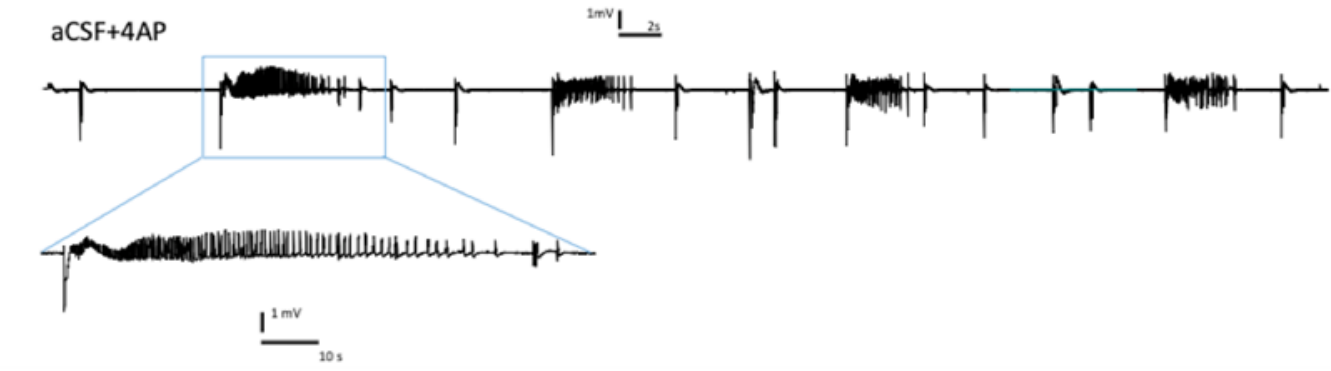

Şekil 8. 4AP ile indüklenmiş alan potansiyel kayıt örnekleri A) İnteriktal deşarj benzeri aktivite kayıt örneği, B) íktal deşarj benzeri aktivite kayıt örneği. (71)

Çünkü TLE modelinde nöbetler genellikle birkaç limbik bölgeyi içerir ve nöbetin başlangıcının ve yayılmasının tam anatomik konumu bilinmemektedir. Ayrıca bu durum hastadan hastaya farkılık gösterebilir. Bu nedenle, TLE ile ilişkili anormallikler için hipokampal kesitlerde bakılması gereken anatomik noktalar belirsizdir. Çalışmalarda epilepsiye bağlı plastisiteye odaklanmak ve bu değişikliklerin ayrıntılarını aydınlatmak daha yararlıdır. Ayrıca kesit çalışmalarından elde edilen verilerdeki değişikliklerin potansiyel olarak "proepileptik" olabileceği parametreleri tanımlamak yeni terapötik hedefler sağlayabilir $(79,88)$.

\subsection{Kesitlerin Biyokimyasal Analizler için Kullanımı: Hi- poksi}

Akut beyin kesiti hazırlığı, tanımlanmış hücre mimarisi, mekanik stabilitesi ve oksijen varyasyonlarına karşı bilinen duyarlılığı ile, oksijen yokluğunun nöronal fizyoloji üzerindeki etkisinin ayrıntılı olarak çalışılabileceği bir in vitro model sağlamaktadır. (89-91). Bir beyin kesitindeki oksijen ortamını uzay-zamansal olarak kontrol edebilme avantajı, canlı beyindeki oksijen ve nöronal fonksiyon arasındaki ilişki hakkında bilgi verecektir. Izole edilmiş bir nöronal dokuyu hipoksik hasara maruz bırakan çoğu çalışma, oksijen kaynağının araştırmacı tarafından düzenlendiği perfüzyon çemberlerine dayanır (92-95). Oksijen kaynağı ile aynı basınçta verilen \%100 N2 gazı ile gazlandırılan yBOS solüsyonunun kesiti perfüze etmesiyle hipoksik olaylar indüklenir (96). In vitro beyin kesitlerindeki çalışmalar, pürin ve pirimidin nükleotid seviyelerinde ve oksijen/glukoz tükenmesi sırasında ve sonrasında meydana gelen canlılık durumunda ciddi değişiklikler olduğunu göstermiştir $(97,98)$. Ayrıca hipoksi gibi iskeminin eşlik eden vasküler ve diğer sistemik yanıtlar nedeniyle beyini yerinde nasıl etkilediğini araştırmak zordur. Bu nedenle ince in vitro beyin kesiti, hipoksinin işleyen sinir dokusunun fizyolo- jisi üzerindeki etkisini incelemek için pratik bir yöntem sağlar. Beyin kesitlerinde tanımlanabilir sinir katmanları içinde gerçekleştirme fırsatı, beynin yakınlarındaki mikro ortamlarının hipoksisine karşı reaktivitedeki farklılıkların karşılaştırılmasına izin verir.

\section{SONUÇ}

Akut beyin kesiti hazırlığı, nöronların ve nöronal dokunun çeşitli fizyolojik koşullara nasıl tepki verdiğinin ayrıntılarını incelemek için ideal bir modeldir. Ex-vivo beyin kesitleri yarım yüzyıldır hayvan beyninde elektrofizyolojik çalışmalar için kullanılmaktadır (99). In vivo hazırlıktan hem daha hızlı, hemde daha ucuzdur. Beyin dokusunun vücuttan çıkarılması, kalp atışının ve solunumun mekanik etkilerini ortadan kaldırır. Bu da hücre içi kayıtların daha uzun alınmasına izin verir. Oksijen, karbondioksit seviyeleri veya hücre dışı sıvının $\mathrm{pH}^{\prime}$ ı gibi kesitin fizyolojik koşulları ayarlanabilir ve korunabilir. Kapalı in vivo sistemde mümkün olmayan kayıt elektrodunun istenilen bölgeye dikkatlice yerleştirilmesi için uygundur. Bir beyin kesitinde izole edilmiş sinaptik devre, asıl bulunduğu bölgedeki devrenin basit bir modelini temsil eder. Hücre kültürlerinde veya homojenleştirilmiş dokuda kaybolan yapısal bağlantılar bu modelde korunur. Beyin kesitleri, beynin geri kalanının ilgilenilen sinir devresi üzerindeki etkilerinin ortadan kaldırılmış olmasıyla daha fazla deneysel kontrol sağlar. Agonistlerin ve antagonistlerin perfüzyonu yoluyla nörotransmitter aktivitesinin hassas manipülasyonuna izin verir. Ancak beyin kesitlerinden elde dilen veriler yorumlanırken, izole edilmiş bir kesitin beyinde mevcut olan olağan giriş çıkış bağlantılarından yoksun olduğu unutulmamalıdır. Ayrıca kesit alma işlemi sürecindeki komplikasyonlar göz önünde bulundurulmalı ve canlı doku hücrelerinin miktarını maksimize etmek için kesim işlemi uygun koşullarda ve hızlı yapılmalıdır. Kesitin uzun süreli perfüzyon ortamında 
dinlendirilmesine dikkat edilmelidir. Kayıt esnasında dokunun, sağlıklı bir hayvandan daha hızlı bozunup yaşlanacağı bilinip, deney kayıt süresi buna gore ayarlanmalıdır.

Etik onam: Çalışma etik onam izni gerektirmemektedir.

\section{Yazar Katkıları:}

Konsept: i.A. , H.Ö.

Literatür Tarama: H.Ö. , I.A.

Tasarım: I.A. , H.Ö.

Veri toplama: H.Ö. , I.A.

Analiz ve yorum: I.A. , H.Ö.

Makale yazımı: H.Ö. , I.A.

Eleştirel incelenmesi: i.A.

Çıkar Çatışması: Herhangi bir çıkar çatışmamız bulunmamaktadır. Finansal Destek: Araştırma kapsamında herhangi bir kurum ya da kuruluştan finansal destek sağlanmamıştır.

\section{Kaynaklar}

1. Kerkut GA, and Wheal HW. (Eds.) Electrophysiology of isolated mammalian CNS preparations. Academic Press. 1981.

2. Yamamoto $\mathrm{C}$, Mcllwain $\mathrm{H}$. Electrical activities in thin sections from the mammalian brain maintained in chemicallydefined media in vitro. J Neurochem. 1966;13(12): 13331343.

3. Molleman A. Patch clamping: an introductory guide to patch clamp electrophysiology. Wiley, West Sussex, Englandisê. 2003.

4. Jefferys JG. Nonsynaptic modulation of neuronal activity in the brain: electric currents and extracellular ions. Physiol Rev. 1995; 75(4): 689-723.

5. Scholfield CN. Electrical properties of neurones in the olfactory cortex slice in vitro, J. Physiol. (London). 1978;275:535546.

6. Voskuyl RA, and ter Keurs HEDJ. Modification of neuronal activity in olfactory cortex slices by extracellular $\mathrm{K}+$, Brain Res. 1981;230:372-377?

7. Lipton $P$, and Whittingham TS. The effect of hypoxia on evoked potentials in the in vitro hippocampus. J. Physiol. (London) 1979;287:427-438.

8. Lipton $\mathrm{P}$, and Heimbach $\mathrm{CJ}$. The effect of extracellular potassium concentrations on protein synthesis in guinea-pig hippocampal slices, J. Neurochem. 1977;28:1347-1354.

9. Lipton $\mathrm{P}$, and Heimbach CJ. Mechanism of extracellular potassium stimulation of protein synthesis in the in vitro hippocampus, J. Neurochem. 1978;31:1299-1307.

10. Lipton $P$, and Robacker K. Glycolysis and brain function: Ko stimulation of protein synthesis and $\mathrm{K}+$ uptake require glycolysis. Fed Proc. 1983;42(12):2875-80.

11. Hablitz JJ, and Lundervold A. Hippocampal excitability and changes in extracellular potassium. Exp. Neurol. 1981;71:410-420.

12. King G1, and Somjen GG. Extracellular calcium and action potentials of soma and dendrites of hippocampal pyramidal cells. Brain Res. 1981;226:339-343.

13. Kimelberg HK, Biddlecome R, Narumi S, and Bourke RS. ATPase and carbonic anhydrase actuities of bulk-isolated neurons, glia and synaptosome fractions from rat brain. Brain Res. 1978;141:305-323.

14. Grisar $T$, and Franck $G$. Effect of changing potassium ion concentrations on rat cerebral slices in vitro: A study during development. J. Neurochem. 1981;36:1853-1857.

15. Pittman QJ, Blume HW, and Renaud LP. Connections of the hypothalamic paraventricular nucleus with the neurohypophysis, median eminence, amygdala, lateral septum and midbrain periaqueductal gray: An electrophysiological study in the rat. Brain Res. 1981;215:15-28.

16. Jefferys JGR, and Haas HL. Synchronized bursting of CAl hippocampal pyramidal cells in the absence of synaptic transmission, Nature 1982;300:448-450.

17. Richards $C D$, and Sercombe R. Calcium, magnesium and the electrical activity of guinea-pig olfactory cortex in vitro. J. Physiol. (London) 1970;211:571-584.

18. Hackett JT. Calcium dependency of excitatory chemical synaptic transmission in the frog cerebellum in vitro. Brain Res. 1976;114:35-46.

19. Dingledine R, and Somjen G. Calcium dependence of synaptic transmission in the hippocampal slice. Brain Res. 1981;207:218-222. 'in

20. Schaer $\mathrm{H}$. Decrease in ionized calcium by bicarbonate in physiological solutions. Pfliigers Arch. 1974;347:249-254.

21. Dienel GA, Hertz L. Glucose and lactate metabolism during brain activation. J Neurosci Res. 2001;66:824-838.

22. Christie JM, Jahr CE. Multivesicular release at Schaffer collateral-CA1 hippocampal synapses. J Neurosci. 2006;26:210-216.

23. Schurr A, Payne RS, Miller JJ, Rigor BM. Study of cerebral energy metabolism using the rat hippocampal slice preparation. Methods. 1999;18:117-126.

24. Cater HL, Chandratheva A, Benham CD, Morrison B III, Sundstrom LE. Lactate and glucose as energy substrates during, and after, oxygen deprivation in rat hippocampal acute and cultured slices. J Neurochem. 2003;37:13811390.

25. Alger BE, Nicoll RA. Epileptiform burst afterhyperpolarization: Calcium-dependent potassium potential in hippocampal CA1 pyramidal cells. Science. 1980;210:1122-1124.

26. Brown DA, Wong RKS, Prince D. Spontaneous miniature synaptic potentials in hippocampal neurons. Brain Res. 1979;177:194-199.

27. Aydın-Abidin S, Abidin I. 7,8-Dihydroxyflavone potentiates ongoing epileptiform activity in mice brain slice. Neuroscience Letters. 2019;703:25-31.

28. Llinas R and Sugimori M. Electrophysiological properties of in vitro Purkinje cell somata in mammalian cerebellar slices. J. Physiol. (London) 1980a;305:171-195.

29. Spray DC, Harris AL, and Bennett MVL. Gap junctional conductance is a simple and sensitive function of intracellular pH. Science. 1981;211:712-715. Silp?

30. Marshall KC, and Engberg I. The effects of hydrogen ion on spinal neurons. Can. J. Physiol. Pharmacol. 1980;58:650655.

31. Franck G. Brain slices, The Structure and Function of Nervous Tissue, Volume VI. Structure and Physiology (G. H. Bourne, ed.), Academic Press, New York. 1972:417- 465.

32. Xiong $\mathrm{H}$, Xia J. Preparation and use of rodent hippocampal slices.Current Laboratory Methods in Neuroscience Research. 2014: 95-103.

33. Teyler TJ. Brain slice preparation: Hippocampus, Brain Res. Bull. 1980;5:391-403.

34. Garthwaite J, Woodhams PL, Collins MJ, and Balazs R. On 
the preparation of brain slices: Morphology and cyclic nucleotides, Brain Res. 1979;173:373-377.

35. White WF, Nadler JV, and Cotman CW. A perfusion chamber for the study of CNS physiology and pharmacology in vitro, Brain Res. 1978;152:591-596.

36. Schwartzkroin PA. Characteristics of CAl neurons recorded intracellularly in the hippocampal slice. Brain Res. 1975;85:423-435.

37. $\mathrm{Li} \mathrm{CL}$, and Mcllwain $\mathrm{H}$. Maintenance of resting membrane potentials in slices of mammalian cerebral cortex and other tissues in vitro. J. Physiol. 1957;139:178-190.

38. Haas HL, Schaerer B, and Vosmansky M. A simple perfusion chamber for the study of nervous tissue slices in vitro, J. Neurosci. Methods. 1979;1:323-325.

39. Nicoll RA, Alger BE. A simple chamber for recording from submerged brain slices. J Neurosci Methods. 1981;4: 153156.

40. Stopps M, Allen N, Barrett R, Choudhury HI, Jarolimek W, Johnson $\mathrm{M}$, et al. Design and application of a novel brain slice system that permits independent electrophysiological recordings from multiple slices. J Neurosci Methods. 2004;132:137-48.

41. Dunlop J, Roncarati R, Jow B, Bothmann H, Lock $T$, Kowal $D$, et al. In vitro screening strategies for nicotinic receptor ligands. Biochem Pharmacol. 2007;74:1172-81.

42. Graef JD, Wei H, Lippiello PM, Bencherif M, Fedorov N. Slice XVIvo: A novel electrophysiology system with the capability for 16 independent brain slice recordings. Journal of Neuroscience Methods. 2013;212: 228-233.

43. Finkel $A$ and Bookman R. Current Protocols in Neuroscience. 1997 by John Wiley and Sons, Inc. 6.1.1-6.1.6.

44. Neher E, Sakmann B. Single-channel currents recorded from membrane of denervated frog muscle fibres. Nature. 1976;260:799-802.

45. Hamill OP, Marty A, Neher E, Sakmann B, Sigworth FJ. Improved Patch-Clamp Techniques for High-Resolution Current Recording from Cells and Cell-Free Membrane Patches. Pflügers Arch. 1981;391:85-100. [iche?

46. Horn R, Marty A. Muscarinic Activation of lonic Currents by a New Whole-Cell Recording Method. J. Gen. Physiol. 1988;92:145-159.

47. Ashcroft, F.M. Ion Channels and Disease: Channelopathies. Boston: Academic Press, Newyork, 2000.

48. Kass RS. The channelopathies: novel insights into molecular and genetic mechanisms of human disease. J Clin Invest. 2005;115:1986-89.

49. Thompson RF. The search for the engram. Am. Psychol. 1976;31:209-227.

50. Teyler TJ, Cavus I, Coussens C, DiScenna P, Grover LM, Lee YP, and Little Z. Brain Slices in Basic and Clinical Research (Schurr, A., and Rigor, B., Eds.), CRC Press, Boca Raton, FL.). 1995.

51. Bliss TVP, and Collingridge GL. A synaptic model of memory: Long-term potentiation in the hippocampus. Nature. 1993;361:31-39.

52. Martin S, Grimwood $P$, and Morris RGM. Synaptic plasticity and memory: An evaluation of the hypothesis. Annu. Rev. Neurosci. 2000;23:649-711.

53. Bliss TVP, and Lomo T. Long-lasting potentiation of synaptic transmission in the dentate area of the anaesthetized rabbit following stimulation of the perforant path. J. Physiol. 1973;232:331-356
54. Collingridge GL, Kehl SJ, and McLennan H. Excitatory amino acids in synaptic transmission in the Schaffer collateralcommissural pathway of the rat hippocampus. J. Physiol. 1983;334:33-46.

55. Lynch G, Larson J, Kelso S, Barrionuevo G, and Schottler F. Intracellular injections of EGTA block induction of hippocampal long-term potentiation. Nature. 1983;305: 719721.

56. Frey U, Huang YY, and Kandel ER. Effect of cAMP stimulate a late stage of LTP in hippocampal CA1 neurons. Science. 1993;260: 1661-1664.

57. Nguyen PV, Abel T, and Kandel ER. Requirement of a critical period of transcription for induction of late phase of LTP. Science. 1994;265: 1104-1107.

58. Abel $T$, Nguyen PV, Barad M, Deuel $T$, Kandel ER, and Bourtchouladze R. Genetic demonstration of a role for PKA in the late phase of LTP and in hippocampus-based long-term memory. Cell. 1997;88: 615-626.

59. Giese KP, Fedorov NB, Filipkowski RK, and Silva AJ. Autophosphorylation at Thr286 of the alpha calcium-calmodulin kinase II in LTP and learning. Science. 1998;279: 870-873.

60. Kandel ER. The molecular biology of memory storage: A dialogue between genes and synapses. Science. 2001;294: 1030-1038.

61. Grover LM, and Teyler TJ. Two components of long-term potentiation induced by different patterns of afferent activation. Nature. 1990;347:477-479.)

62. Trevelyan AJ, Sussilo D, Watson BO, Yuste R. Modular propagation of epileptiform activity: evidence for an inhibitory veto in neocortex. J Neurosci. 2006;26:12447-12455.

63. Bear J, Lothman EW. An in vitro study of focal epileptogenesis in combined hippocampal-parahippocampal slices. Epilepsy Res. 1993;14(3): 183-193.

64. Pinto DJ, Patrick SL, Huang WC, Connors BW. Initiation, propagation and termination of epileptiform activity in rodent neocortex in vitro involve distinct mechanisms. J Neurosci. 2005;25: 8131-8140.

65. Voskuyl RA, Albus H. Spontaneous epileptiform discharges in hippocampal slices induced by 4 -aminopyridine. Brain Res. 1985;342: 54-66.

66. Perreault $\mathrm{P}$, Avoli M. Physiology and pharmacology of epileptiform activity induced by 4-aminopyridine in rat hippocampal slices. J Neurophysiol. 1991;65:771-785.

67. Perreault $P$, Avoli M. 4-aminopyridine-induced epileptiform activity and a GABA-mediated long-lasting depolarization in the rat hippocampus. J Neurosci. 1992;12:104-115.

68. Avoli M, Barbaroise M, Lucke A, Nagao T, Lopantsev V, Kohling R. Synchronous GABA-mediated potentials and epileptiform discharges in the rat limbic system in vitro. J Neurosci. 1996;16: 3912,3924.

69. Ziburkus J, Cressman JR, Barreto E, Schiff SJ. Interneuron and pyramidal cell interplay during in vitro seizure-like events. J Neurophysiol. 2006; 95:3948-3954.

70. Uva L, Avoli M, de Curtis M. Synchronous GABAa-receptordependent potentials in limbic areas of the in vitro isolated adult guinea pig brain. Eur J Neurosci. 2009;29:911-920.

71. Ozturk H. Phoenixin-14 modulates seizure-like events in amygdala. 6. Uluslararası GAP Matematik-Mühendislik-Fen ve Sağlık Bilimleri Kongresi, Şanlıurfa, 2021:58-64.

72. Bernard C. Hippocampal Slices: Designing and Interpreting Studies in Epilepsy Research. Models of Seizures and Epilepsy. 2006:59-72. 
73. Cronin J, Obenaus A, Houser CR, Dudek FE. Electrophysiology of dentate granule cells after kainate-induced synaptic reorganization of the mossy fibers. Brain Res. 1992;573: 305-310.

74. Hardison JL, Okazaki MM, Nadler JV. Modest increase in extracellular potassium unmasks effect of recurrent mossy fiber growth. J Neurophysiol. 2000;84: 2380-2389.

75. Lynch M, Sutula T. Recurrent excitatory connectivity in the dentate gyrus of kindled and kainic acid-treated rats. J Neurophysiol. 2000;83: 693- 704.

76. Patrylo PR, Dudek FE. Physiological unmasking of new glutamatergic pathways in the dentate gyrus of hippocampal slices from kainite-induced epileptic rats. J Neurophsiol. 1998;79(1):418-29.

77. Patrylo PR, van den Pol AN, Spencer DD, Williamson A. NPY inhibits glutamatergic excitation in the epileptic human dentate gyrus. J Neurophysiol. 1999;82:478-483.

78. Wuarin JP, Dudek FE. Electrographic seizures and new recurrent excitatory circuits in the dentate gyrus of hippocampal slices from kainite-treated epileptic rats. J Neurosci. 1996;16(14):4438-4448.

79. Bernard C, Anderson A, Becker A, Poolos NP, Beck H, Johnston $D$. Acquired dendritic channelopathy in temporal lobe epilepsy. Science. 2004;305(5683):532-5.

80. Brooks-Kayal AR, Shumate MD, Jin H, Rikhter TY, coulter $D A$. Selective changes in single cell GABA(A) receptor subunit expression and function in temporal lobe epilepsy. Nat Med. 1998;4(10):1166-72.

81. Buhl EH, Otis TS, Mody I. Zinc-induced collapse of augmented inhibition by GABA in a temporal lobe epilepsy model. Science. 1996; 271(5247): 369-73.

82. Cossart R, Dinocourt $C$, Hirsch JC, Merchan-Perez A, De Felipe J, Ben-Ari Y, et al. Dendritic but not somatic GABAergic inhibition is decreased in experimental epilepsy. Nat Neurosci. 2001. 4(1):52-62.

83. Esclapez M, Hirsch JC, Khazipov R, Ben-Ari Y, Bernard C. Operative GABAergic inhibition in hippocampal CA1 prymidal neurons in experimental epilepsy. Proc Natl Acad Sci. 1997;94(22):12151-6.

84. Esclapez M, Hirsch JC, Ben-Ari Y, Bernard C. Newly formed excitatory pathways provide a substrate for hyperexcitability in experimental temporal lobe epilepsy J. Comp. Neurol. 1999;408(4): 449-460.

85. Nusser Z, Sieghart W, Somogyi P. Segregation of different GABAA receptors to synaptic and extrasynaptic membranes of cerebellar granule cells. J Neurosci. 1998;18: 1693-1703.

86. Ratzliff AH, Howard AL, Santhakumar V, Osapay I, Soltesz I. Rapid deletion of mossy cells does not result in a hyperexcitable dentate gyrus: Implications for epileptogenesis. J Neurosci. 2004;24: 2259-2269.

87. Scharfman HE, Goodman JH, Sollas AL. Granule-like neurons at the hilar/CA3 border after status epilepticus and their synchrony with area CA3 pyramidal cells: Functional implications of seizure-induced neurogenesis. J Neurosci. 2000;20: 6144-6158.

88. Su H, Sochivko $D$, Becker $A$, Chen J, Jiang $Y$, Yaari $Y$, and Beck $\mathrm{H}$. Upregulation of a T-type $\mathrm{Ca} 2+$ channel causes a long-lasting modification of neuronal firing mode after status epilepticus. J Neurosci. 2002;22: 3645 - 3655.

89. Medvedeva YV, Lin B, Shuttleworth CW, Weiss JH. Intracellular Zn2+ accumulation contributes to synaptic failure, mitochondrial depolarization, and cell death in an acute slice oxygen-glucose deprivation model of ischemia. J. Neuroscience. 2009;29: 1105-1114.

90. Stork CJ, Li YV. Rising zinc: a significant cause of ischemic neuronal death in the CA1 region of rat hippocampus. J. Cerebral Blood Flow \& Metabolism. 2009;29: 1399-1408.

91. Rambani K, Vukasinovic J, Glezer A, Potter SM. Culturing thick brain slices: an interstitial 3D microperfusion system for enhanced viability. J. Neuroscience Methods. 2009;180: 243-254.

92. Taylor $\mathrm{CP}$, Weber ML, Gaughan $\mathrm{CL}$, Lehning EJ, LoPachin RM. Oxygen/glucose deprivation in hippocampal slices: altered intraneuronal elemental composition predicts structural and functional damage. J. Neuroscience. 1999;19: 619-629.

93. Huchzermeyer C, Albus K, Gabriel HJ, Otahal J, Taubenberger N, et al. Gamma oscillations and spontaneous network activity in the hippocampus are highly sensitive to decreases in $\mathrm{pO} 2$ and concomitant changes in mitochondrial redox state. J. Neuroscience. 2008;28: 1153-1162.

94. Hoffmann U, Pomper J, Graulich J, Zeller M, Schuchmann, et al. Changes of neuronal activity in areas CA1 and CA3 during anoxia and normoxic or hyperoxic reoxygenation in juvenile rat organotypic hippocampal slice cultures. Brain Research. 2006;1069: 207-215.

95. Huang $\mathrm{Y}$, Williams JC, Johnson SM. Brain slice on a chip: opportunities and challenges of applying microfluidic technology to intact tissues. Lab on a Chip. 2012;12: 2103-2117.

96. Dong W-Q, Schurr A, Reid K H, Shields CB, West CA. The rat hippocampal slice preparation as an in vitro model of Iskemia. Stroke. 1988;19(4): 498-502.)

97. Pissarek M, Reinhardt R, Reichelt C, Manaenko A, Krauss G, Illes $P$. Rapid assay for one-run determination of purine and pyrimidine nucleotide contents in neocortical slices and cell cultures. Brain Res.Protoc. 1999;4:314-321.

98. Gunther A, Manaenko A, Franke H, Dickel T, Berrouschot J, Wagner A, et al. Early biochemical and histologicalchanges during hyperbaric or normobaric reoxygenation after in vitroischemia in primary corticoencephalic cell cultures of rats. Brain Res. 2002;946:130-138.

99. Collingridge $\mathrm{GL}$. The brain slice preparation: a tribute to the pioneer Henry Mcllwain. J. Neurosci. Methods. 1995;59(1):5-9. 